\title{
Pattern of lipid fractions in plasma and cardiovascular tissues under Cryptorchidism in albino rat
}

\section{K. Narasimha Varma, E. Madhuri and M. Bhaskar*}

Department of Zoology, Sri Venkateswara University, Tirupati - 517502 (A.P.), INDIA

*Corresponding author. E-mail: matchabhaskar@yahoo.com

\begin{abstract}
Bilateral cryptorchidism was induced surgically in adult wistar strain male albino rats and lipid fractions such as total lipids, total cholesterol, Free cholesterol, Esterified cholesterol, phospholipids, Triglycerides and free fatty acids were analysed in the plasma, heart and dorsal aorta. The lipid fractions such as triglycerides (56.63\%), free $(20.82 \%)$ and esterified (61.25\%) cholesterol as well as fatty acids in glycerol $(64.42 \%)$ had significant elevation in the plasma of cryptorchid animals. Similarly LDL lipid fractions (64.99\%) were also elevated markedly under cryptorchid conditions which are the markers of the obesity and atherosclerosis. The lipid fractions such as triglycerides $(50.47 \%, 48.17 \%)$, cholesterol $(74.64 \%, 67.7 \%)$ and phospholipids $(42.04 \%, 68.88 \%)$ showed significant elevations in the heart and dorsal aorta of the cryptorchid animals over the control. The heart, dorsal aorta and plasma had significant accumulation of triglycerides and cholesterol fractions, suggesting the possible deposition of lipid fractions in the tissues, which can be attributed to the possible suppression in the mobilization of lipid fractions into energy metabolism. Such an accumulation of lipid fractions under cryptorchid condition can be considered as the development of risk factor for the cardio-vascular disorders.
\end{abstract}

Keywords: Cryptorchidism, Albino rat, Lipid fractions, Cardiovascular,Tissues-Plasma

\section{INTRODUCTION}

Cryptorchidism is one of the important factors which causes infertility in male (Rijli et al., 1995 and Malyshkin, 1997). Cryotorchidism induced testis cell degeneration is mediated by apoptosis probably as the result of increased in testicular temperature. Farouqui et al. (1997) reported that cryptorchid testes exhibited marked degenerative changes in the seminiferous tubules and spermatogonia, impaired and incomplete spermatogenesis. Sertoli cells play a major role in regulating spermatogenesis. Impaired sertoli cells. Which is a marker of sertoli cell function (Demura et al., 1987). Wu and Murono (1996) reported that a novel serbli cell secreted mitogenic factor stimulated proliferation, decreased testosterone formation and Luteinizing hormone/ human chorionic gonadotropin receptor levels. Temperature increased both the secretion of this factor by sertoli cells and responsiveness of Leydig cells to this factor (Wu and Murono 1996). Cryptorchidism and elevation of testicular temperature disturb the elevation of biochemical activities (Main and Waites, 1997). Changes in the hormonal profiles and altered cellular functions in the atrophied tubules might reflect on the metabolic activities of damaged testes (Veracruz et al. 1970 and Shizume, 1987). Galan et al. (1991) reported new born with cryptorchidism has a congenital heart defect. However there are no evidences on the reasons for cardio vascular disorders in cryptorchid animals. Hence the present study has been under taken to study the effect of the cryptorchidism on the distribution of lipid fractions in the plasma and cardio vascular tissues.

\section{MATERIALS AND METHODS}

Adult male Wistar strain albino rats weighing about 125 $\pm 5 \mathrm{~g}$ and $100 \pm 5$ days ages were selected for experimentation and they were divided into 2 batches. Each batch consists of 8 rats. The first batch was treated as control and the second as experimental. The control rats were anaesthetized with anaesthetic ether, perineal area shaved, swabbed with $95 \%$ ethanol, $1 \mathrm{~cm}$ long bilateral incisions were made at the level of the inguinal canals, sutured and treated as sham operated. The second batch rats were anaesthetized with anaesthetic ether and $1 \mathrm{~cm}$ long bilateral incisions were made at the level of inguinal canals and testes were carefully translocated into abdominal cavity with blunt foreceps. Care was taken to avoid damage to the testicular artery. Both the inguinal canals have been sutured with silk thread to prevent the descent of the testes from abdominal cavity. The experimental and sham operated rats were maintained at laboratory conditions $\left(26 \pm 2^{\mathfrak{x} \%} \mathrm{C}\right.$ and $12 \mathrm{hrs}$ of light and $12 \mathrm{hrs}$ of darkness), fed on standard rat diet (Hindustan Lever Ltd., Mumbai) and water was supplied ad libitum for a period of 60 days. On the $61^{\text {st }}$ day the animals were sacrificed by cervical dislocation and the tissues were 
Table 1. Showing the alterations in lipid fractions of plasma, heart, dorsal aorta of control and cryptorchid rats. Mean \pm S.D of eight observations each.

\begin{tabular}{|c|c|c|c|c|c|c|}
\hline \multirow[t]{2}{*}{ Parameter } & \multicolumn{2}{|c|}{ Plasma } & \multicolumn{2}{|c|}{ Heart } & \multicolumn{2}{|c|}{ Dorsal Aorta } \\
\hline & Control* & Experimental* & Control** & Experimental $* *$ & Control** & Experimental $* *$ \\
\hline Total lipids & $\begin{array}{l}326.13 \\
\pm 2.14\end{array}$ & $\begin{array}{c}496.48 \\
+3.25 \\
+52.23 \\
+\end{array}$ & $\begin{array}{l}37.88 \\
\pm 0.95\end{array}$ & $\begin{array}{c}50.82 \\
\pm 0.88 \\
+34.16 \\
+\end{array}$ & $\begin{array}{r}43.90 \\
+1.275\end{array}$ & $\begin{array}{c}67.563 \\
\pm 1.303 \\
+53.9 \\
+\end{array}$ \\
\hline $\begin{array}{c}\text { Total } \\
\text { Cholesterol }\end{array}$ & $\begin{array}{r}92.59 \\
\pm 2.24\end{array}$ & $\begin{array}{c}146.41 \\
+2.38 \\
+58.12 \\
+\end{array}$ & $\begin{array}{r}1.412 \\
\pm 0.03\end{array}$ & $\begin{array}{c}2.466 \\
\pm 0.03 \\
+74.64 \\
+\end{array}$ & $\begin{array}{c}2.44 \\
\pm 0.077\end{array}$ & $\begin{array}{c}4.092 \\
+0.173 \\
+67.7 \\
+\end{array}$ \\
\hline Free Cholesterol & $\begin{array}{c}24.39 \\
+1.031\end{array}$ & $\begin{array}{c}29.47 \\
+1.46 \\
+20.82 \\
+\end{array}$ & $\begin{array}{c}0.522 \\
\pm 0.009\end{array}$ & $\begin{array}{c}0.950 \\
+0.013 \\
+82.0 \\
+\end{array}$ & $\begin{array}{c}0.705 \\
+0.045\end{array}$ & $\begin{array}{c}1.199 \\
+0.088 \\
+70.07 \\
+\end{array}$ \\
\hline $\begin{array}{c}\text { Esterified } \\
\text { Cholesterol }\end{array}$ & $\begin{array}{r}68.13 \\
\pm 1.37\end{array}$ & $\begin{array}{c}109.86 \\
\pm 1.82 \\
+61.25\end{array}$ & $\begin{array}{c}0.92 \\
\pm 0.055\end{array}$ & $\begin{array}{c}1.496 \\
\pm 0.018 \\
+62.6\end{array}$ & $\begin{array}{c}1.71 \\
\pm 0.011\end{array}$ & $\begin{array}{c}2.827 \\
\pm 0.004 \\
+65.32\end{array}$ \\
\hline $\begin{array}{c}\text { HDL } \\
\text { Cholesterol }\end{array}$ & $\begin{array}{r}84.34 \\
\pm 1.27\end{array}$ & $\begin{array}{c}+ \\
57.13 \\
+1.28 \\
-32.26 \\
+\end{array}$ & NA & $\begin{array}{c}+ \\
\text { NA }\end{array}$ & NA & $\begin{array}{c}+ \\
\text { NA }\end{array}$ \\
\hline $\begin{array}{c}\text { LDL } \\
\text { Cholesterol }\end{array}$ & $\begin{array}{r}69.67 \\
\pm 1.36\end{array}$ & $\begin{array}{c}114.95 \\
+1.47 \\
+64.99 \\
+\end{array}$ & NA & NA & NA & NA \\
\hline Triglycerides & $\begin{array}{l}31.41 \\
\pm 0.58\end{array}$ & $\begin{array}{c}49.2 \\
\pm 0.72 \\
+56.63 \\
+\end{array}$ & $\begin{array}{c}2.988 \\
\pm 0.043\end{array}$ & $\begin{array}{c}4.496 \\
\pm 0.022 \\
+50.47 \\
+\end{array}$ & $\begin{array}{c}3.186 \\
\pm 0.016\end{array}$ & $\begin{array}{c}4.721 \\
\pm 0.037 \\
+48.17 \\
+\end{array}$ \\
\hline Phospholipids & $\begin{array}{r}25.18 \\
+1.42\end{array}$ & $\begin{array}{c}38.4 \\
+1.18 \\
+52.5 \\
+\end{array}$ & $\begin{array}{r}23.69 \\
\pm 0.33\end{array}$ & $\begin{array}{c}33.65 \\
\pm 0.48 \\
+42.04 \\
+\end{array}$ & $\begin{array}{c}3.60 \\
+0.117\end{array}$ & $\begin{array}{c}6.08 \\
+0.449 \\
+68.88 \\
+\end{array}$ \\
\hline Free Fatty acids & $\begin{array}{l}25.61 \\
\pm 0.74\end{array}$ & $\begin{array}{c}42.11 \\
+0.87 \\
+64.42 \\
+\end{array}$ & $\begin{array}{r}13.233 \\
\pm 0.191\end{array}$ & $\begin{array}{c}22.535 \\
\pm 0.665 \\
+70.3 \\
+\end{array}$ & $\begin{array}{c}25.20 \\
\pm 0.438\end{array}$ & $\begin{array}{c}33.495 \\
\pm 0.351 \\
+32.91 \\
+\end{array}$ \\
\hline
\end{tabular}

+\% Increase; - \% Decrease; * Values are in $\mathrm{mg} / 100 \mathrm{ml}$ of blood; ** Values are in $\mathrm{mg} / \mathrm{gm}$ dry wt. of the tissue.

NA : Not applicable; + Significant level $(\mathrm{P}<0.001)$.

isolated carefully, chilled rapidly in ice box and utilized for biochemical analysis. The blood of these animals was collected. Plasma was separated from the blood and stored in cold $\left(0^{\circ} \mathrm{C}\right)$ and used for biochemical studies. The total lipids (Folch et al., 1969), total cholesterol and Esterified colesterol (Natelson, 1971a), phospholipids (Zelversmidth and Davis, 1950), Free Fatty acids (Natelson, 1971b), triacyl glycerol (Netelson, 1971c), HDL cholesterol (Burstein and Chen, 1970). LDL cholesterol (Friedewald et al., 1972), were estimated in plasma, heart and dorsal aorta.

\section{RESULTS}

The total lipid, total cholesterol, free cholesterol esterified cholesterol, and LDL cholesterol contents of the plasma were significantly increased over the control in cryptorchid animals. HDL cholesterol content was decreased over the control. Similarly triglycerides, phospholipids, free fatty acids contents in plasma were significantly elevated in the cryptorchid animals over the controls (Table 1).

The cardiac tissue of the cryphorchid animals showed an overall increase in the lipid fractions over the controls. The total, free and esterified cholesterol levels were significantly increased in cryptorchid rats over the controls. Cardiac tissue also showed elevated levels of phospholipids, triglycerides and free fatty acids under abdominal condition of the testis. Similarly the lipid 
fractions of dorsal aorta were also increased conspicuously under cryptorchid condition. (Table 1)

\section{DISCUSSION}

The cryptorchid condition of the testis resulted into overall elevation in the plasma lipid fractions when compared to the controls. The total lipid content of the plasma was significantly higher, indicating either increased addition from synthetic sites or decreased utilization by the tissue. The tissue metabolism in male body has a direct relation ship with the testosterone level of circulation (Chase et al., 1957 and Zipt et al., 1978). Since there was significant decrease in the circulating levels of teststerone in cryptorchid animals, (Friedman et.al., $1994 \mathrm{Wu}$ and Murono, 1996). The possibility of suppressed oxidative metabolism of the tissues can be expected. Since the plasma lipids were actively taken up by the tissues into oxidative metabolism, the suppressed metabolic activities of the tissue seem to be responsible for the accumulated lipid fractions in the plasma. The cholesterol fractions were largely accumulated with particular reference to LDL cholesterol, which may be due to decreased steroidogenesis in the body under cryptorchid condition (Pereira et al., 1993 and Fried man et al., 1994). Therefore, the accumulated plasma lipid fractions in the cryptorchid animals suggests the possibility of cardio vascular risk factor.

The cardiac tissue accumulated the lipid fraction under cryptorchid condition, which can be related to the decreased metabolic activities of the tissue. The accumulation of lipid fractions with particular reference to triglycerides in the cardiac tissue may be prone to cardiac disorders. Similarly dorsal aorta also had marked accumulation of the lipid fractions under cryptorchid condition, which can be comparable to a condition of atherosclerosis (Morimoto et al., 1986; Nossen et al., 1986).

Thus the cardio vascular tissues had remarkable accumulation of lipid fractions under the cryptorchid condition, comparable to the major cardio vascular disorders, the results of the present study were indicative of generating of risk factors for the cardio vascular disorders under cryptorchid condition.

\section{REFERENCES}

Burstein P.N. and Chen, C. M.(1970). Diabetes insipidus, nephrogenic type, complicating pregnancy: a case report. Am. J. Obstet. Gynecol., 108(8):1292-3.

Chase, M.P., I.I. Geschwind and H.A. Bern (1957). Synergistic role of prolactin in response to male rat sex accessories to androgen. Proc.Soc.Exp.Biol.Med., 94: 680-683.

Demura, R., Suzuki, T., Nakamura, S., Komatsu, H., Jibiki, K., Odagiri, E., Demura, H.and Shizume, K. (1987). Effect of uni and bilateral cryptorchidism on testicular inhibin and testosterone secretion in rats. Endocrinol Jpn., Dec 34(6); 911-7.
Farooqui, S.M., Al-Bagdadi, F.O., Donnell, J.M. and Stont,R. (1997). Degenerative changes in spermatogonare associated with loss of glucose transporter (Glut 3) in abdominal testis of surgically induced unitaferal cryptorchidism in rats. Biochem.Biophys.Res.Commun.,236 (2): 407-12.

Folch, J.M., Lees, M.P. and Stane-stanley, G.H. (1969). A simple method for the isolation and purification of total lipids from animal tissues. J.Biol. Chem., 226: 497.

Friedewald, W.T., Levy, R.I. and Fredrickson, D.S. (1972). Estimation of the concentration of low density lipoprotein cholesterol in plasma, without use of the preparative ultracentrifuge. Clin. Chem., 18(6): 499-502.

Friedman, R.M., Lopez, F.J., Tucker, J.A., King, L.R. and Nigrovillar, A. (1994). Fertility after cryptorchidsm; a comparative analysis of early orchidopexy with and without concomitant hormonal therapy in the young male rat. J.Urol. Jan., 15(1): 227-35.

Galan, Francisco, Maria soledad Agerilar, Juan Gonzalez, Fernando celmente, Rafael sanchez, Marmel Topia and Manuel Moya. (1991). Interstitial 15q deletion without a classic praderwilli phenotype. Am.J.Med.Genet. ,38(4); 532-534

Main, S.J. and Waites, G.M.H. (1997). The blood-testis barrier and temperature damage to the testis of rat. J.Reprod. Fertil., 51: 439-450.

Malyshkin, (1997). In; the interaction of changes in the genitilia in the pathogenesis of sterility in men. Lik sprava, MayJune (3) 83-7.

Morimoto, Shinji, Yoshikazu Haisa, Toshihiro maeda, Michinori Harada, Tasuya wada, Tsukasa, Aihara, Masaaki Band, Yoshihiro Nakai, Yoshihiro Kataoka and Hiroyoshi Mori. (1986). Relation of serum apolipoprotein and lipoprotein and coronary atherosclerosis. Respir. Cire., 134 (1): 1221-1226.

Natelson, S. (1971a). Total cholesterol procedure Lieberamann - Burchard reagent. In: Techniques of clinical chemistry. Charles C. Thomas publishers, spring field USA, Illinois, $3^{\text {rd }}$ edn. 263.

Natelson, S. (1971b). Free fatty acids in serum. In: Techniques of clinical chemistry, charles c. Thomas publishers, Spring field USA Illinois, $3^{\text {rd }}$ edn., p-477-481.

Natelson, S. (1971c). Triglycerides In: Techniques of clinical chemistry charles C- Thomas publishers, Spring field. USA $3^{\text {rd }}$ edn. Illinois. P 720-723.

Nossen, J.O., Rustan, A.C., Bjørneboe, G.E., Bjørneboe, A., Drevon, C.A. (1986). Lipoproteins and arteriosclerosis. From cell biology to environmental factors. Tidsskr Nor Laegeforen. Oct 30; 106(30):2495-9.

Pereira O.C., Picarelli, Z.P., Abreu L.C. (1993). "Experimental cryptorchidism in pre-pubertal rats; some effects on reactivity of the seminal vesicle to catecholamines". Pharmacol. Res. Sep., 28(2): 175-81.

Rijli, Filippo, M, Robert Matyas, Massimo pellegrini, Andree Dierich, Peter Gruss, pascal Dolle and Pierre chambon. (1995). Cryptorchidism and homeotic transformations of spinal nerves and vertebrae in Hoxa - 10 mutant mice. Proceedings of the National Academy of Sciences of the united states of America., 92 (18): 8185-8189.

Shizume, K. (1987). Effect of uni and bilateral cryptorchidism on testicular inhibin and testosterone secretion in rats. Endocrinol Jpn. Dec. 34 (6):91 1-7. 
Veracrug, N.C., Gomes W.R., and VanDemark, N.L. (1970). The effect of steroid and gonadotrophic hormones invitro on the metabolic activity of normal and cryptorchid rat testicular tissues. Biol. Reprod., 2: 376.

Wu, N. and Murono, E.P.(1996). Temperature and germ cell regulation of Leydig cell proliferation stimulated by sertoli cell-secreted mitogenic factor, a possible role in cryptorchidism. Andrologia, Sept-Oct; 28 (5): 247-57.

Zipt, W.B., Payne, A.H. and Kelch, R.P. (1978). Prolactin growth hormone and luetinizing hormone in the maintenance of testicular luteinizing hormone receptors. Endocrinol., 103: 595-599. 